\title{
Medicine Card as Innovation Learning in Periodic Table of Elements for Pharmaceutical Vocational Students
}

\author{
Zulfah $^{1, *}$, Eka Statistika ${ }^{1}$, Eti Sukriani ${ }^{1}$ \\ ${ }^{1}$ Department of Chemistry Education, Graduate School, \\ Yogyakarta State University, Indonesia \\ *Corresponding author: zulfahzuu@gmail.com
}

\begin{abstract}
The innovation in this instruction was the use of medicine card as a learning media of periodic table of elements. This research aimed to know the process of learning conducted by using medicine card and to know the students' motivation and learning outcomes as the result of the implementation of medicine card in the classroom activity. This research used a quantitative descriptive method. The implementation of the media was conducted in fourfold meetings in Health Vocational School of Sadewa, Yogyakarta, Indonesia. A SWOT analysis was conducted at the beginning of the learning innovation and was followed by the observation and the preparation of material and media. The class activity began with explanations of medicine card games, group divisions, game execution, and confirmation. The final step was evaluated using a questionnaire of motivation and post-test problems. The result of the questionnaire indicated that the students' motivation was in the good criterion and the learning outcomes of students showed that they had an enough criterion.
\end{abstract}

Keywords: innovation, periodic table of elements, medicine card

\section{INTRODUCTION}

In the current era of globalization, the development of technology and information is increasingly advanced in various aspects of life, one of them in the field of education in Indonesia. Education in Indonesia need the technological and information advances specifically for innovation ideas that are expected to be able to achieve efficiency and effectiveness. The field of chemical education in following the development and the demands in the achievement of learning in the field of chemical education required innovations in chemistry learning which aims to improve the quality of motivation and learning outcomes. In this case the researchers innovate in vocational high schools, namely the school is Health Vocational School of Sadewa, because based on the results of observations there are still weaknesses at the school on facilities and infrastructure and there is no special laboratory chemistry, the number of classrooms where the learning and teaching process is still lacking in meetings so it has to be divided into morning and afternoon classes, and most importantly there is still a lack of learning media and innovative learning in chemistry at Sadewa Health Vocational School. Based on this background then in need of innovations in the process of learning and teaching at the school, in this case, researchers make innovations by making learning media become more creative in chemistry learning through medicine card media. Daryanto (2010) stated that learning media is anything that can be used to channel the message from sender to recipient so that it can stimulate the mind, feeling, attention, and interest and attention of learners so that the learning process can happen. 
Updates or innovations that must be made to improve the quality of education in Indonesia include aspects of technological development used in the educational process, the education system implemented, even innovations that directly relate to the learning process of innovation on curriculum, learning strategies, teaching methods or models applied in teaching and learning process. Innovation is an idea, goods, events, methods perceived or observed as a new thing for a person or a group of people (both) in the form of the invention or discovering (Sa'ud, 2010: 3). Innovation is done to achieve a specific goal or to solve a particular problem. In Sa'ud's opinion that an innovation must be something that can provide solutions to the problems that occur. The educational innovation is a new change, and qualitatively different from the (previously existing), and deliberately attempted to improve the ability to achieve certain goals in education. The main purpose of innovation is to increase the sources of energy, money, and facilities including organizational structure and procedures. Meanwhile, the purpose of educational innovation is to improve the efficiency, relevance, quality and effectiveness of the facilities and the number of learners as much as possible with the greatest educational outcomes (according to the criteria of learners' needs, community and development) using resources, personnel, money, tools and time in the smallest amount.

Motivation explains what makes people do things, keeps them up, and helps them accomplish tasks. This means that the concept of motivation is used to describe the desire to behave, the direction of behavior (choice), the intensity of behavior (effort, sustainability), and the real settlement or achievement (Pintrich, 2003). In the learning activities, the motivation can be said as the overall driving force within the students that leads to learning activities, which ensures the continuity of the learning activities and gives direction to the learning activities, so that the desired goal by the learning subject can be achieved (Sardiman, 2000). Brophy (2004) stated that the motivation of learning prioritizes cognitive responses, the tendency of students to achieve meaningful and useful academic activities and the University of North Sumatra 13 tries to benefit from such activity. Students who have the motivation to learn will pay attention to the lessons delivered, read the material so they can understand it, and use certain learning strategies that support. In addition, students also have an intense involvement in such learning activities, high curiosity, search for related materials to understand a topic and complete the assigned task. Students who have motivated learning will depend on whether the activity has interesting content or a fun process. In essence, learning motivation involves learning objectives and related strategies in achieving these learning goals (Brophy, 2004).

Motivation to learn is one factor that can affect and relate to students' learning outcomes, A student who has high motivation has a tendency to have good learning outcomes. There are two factors that affect the learning achievement of internal factors and external factors (Sugihartono, 2012: 76). Learning achievement is one of the learning outcomes of learners on cognitive aspects. There are many factors that influence the learning outcomes of learners, among others, cognitive, affective, and psychosocial aspects. In the middle of the twentieth century, researchers first began researching and measuring affective aspects and measured in a more systematic way. Affective aspects are thought to contribute significantly to a person's learning process (Alci, 2015). Assessment of chemistry learning achievement of learners preceded by measurement of chemistry learners learners (Subali, 2012: 1). This assessment is defined as a means used to determine the level of knowledge and skills of learners whose results can be used for decision-making in the form of evaluation.

The purpose of the study was to know the process of implementing instructional innovation with medicine card on the material of periodic elements system. Then, we want to know the result of using media medicine card in terms of the student's motivation and learning outcomes. 


\section{MATERIALS AND METHODS}

This research used a quantitative descriptive method. The implementation of the media was conducted in four-fold meetings in Health Vocational School of Sadewa, Yogyakarta, Indonesia, and the sample was taken that is pharmacy class from all health classes with cluster random sampling. Instrument research include of observation sheet, questionnaire motivation for students consists of 20 statements with Likert scale filled by pharmacy class students after innovation or use of medicine card, while post test problem, It consists of 25 multiple choice questions to measure students' learning outcomes in SPU Materials, and for medicine card, consists of 2 components, medicine card and empty periodic table. Medicine card used has the characteristics of drug images that are familiar to students is a drug that is commonly used every day and easily found in the market. In addition, there is a compound formula that is covered. Behind the cards are adhesive for easy attachment to the periodic table of elements.

Research procedure:
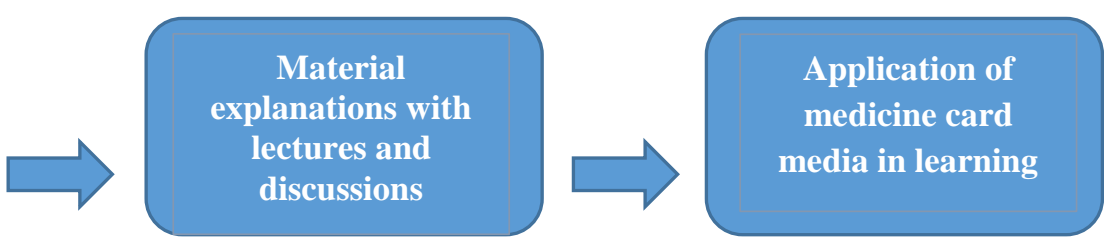

Analyze post test

To see student learning result and motivation, post test data and motivation questionnaire are then analyzed and categorized by categories according to Widoyoko (2009: 238) in Table 1 below:

Table 1. Ideal Rating Categories

\begin{tabular}{|c|c|}
\hline Score & Category \\
\hline 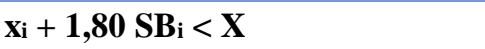 & Very good \\
\hline $\mathrm{x}_{\mathrm{i}}+0,60 \mathrm{SB}_{\mathrm{i}}<\mathrm{X} \leq \mathrm{x}_{\mathrm{i}}+1,80 \mathrm{SB}_{\mathrm{i}}$ & Good \\
\hline$x_{i}-0,60 S_{i}<X \leq x_{i}+0,60 S_{i}$ & Enough \\
\hline$x_{i}-1,80 S_{i}<X \leq x_{i}-0,60 S_{i}$ & Less \\
\hline $\mathrm{X} \leq \mathrm{x}_{\mathrm{i}}-1, \mathbf{8 0} \mathrm{SB}_{\mathrm{i}}$ & Very less \\
\hline
\end{tabular}

\footnotetext{
Description:

$\mathrm{X}=$ The actual score

$\mathrm{x}_{\mathrm{i}} \quad=$ Average ideal score

$\mathrm{SBi}=$ standard deviation ideal
} 


\section{RESULT AND DISCUSSION}

Creativity and innovation not come naturally to the person. Innovation in education refers to making of new things to a learning process. Innovation can be innovative to use for instructional media, innovation on learning model, and other innovations that can improve the quality and quantity of students in the learning. Media innovation and learning model used in this study aim to determine of learning process innovation with medicine card in the material of the periodic elements system and to determine of results using medicine card in terms of student motivation and achievement.

The results measured the using medicine card in this learning innovation to motivation and students' learning outcomes. While the material is the periodic system of elements. It includes the introduction of the periodic system of elements, the periodic properties, and the relationship between drugs and the periodic system of elements. This step of learning innovation starts from the planning stage. Planning started from the beginning of October using SWOT analysis from the school used for this study. The school that researchers use for research is Health Vocational School of Sadewa. From the results of this SWOT analysis, then continues into the process of observation. Observations were conducted once on November 7, 2018. This observation included school observation and observation of the learning process. In school observations, researchers conducted physical observations, including physical observation of the school buildings used, and the environment around the school. While in observation of learning process include teaching by the teacher, state of the student when teacher explain, state of the student when given task, and so on. The results of this observation are then used as a provision in making learning innovations. Implementation of learning innovation at Health Vocational School of Sadewa. done three times, Innovation first day was done on November 14, 2016. In the implementation of learning innovation this time done by the conventional method, that is the lecture. Traditionally used media, worksheet, whiteboards, and markers, without using other learning media. The sub-material used is the introduction of the elemental periodic system, the relationship between the configuration with the periodic table of elements, and explains little about the medicines consisting of the elements in the table. The second implementation of learning innovation was conducted on 21 November 2016. In this meeting, researchers used the model TGT (Team Games Tournament) and Medicine card media. Models and media are used in the learning process so that researchers can achieve the desired goals. Media Medicine card consists of a blank Periodic Table (without any elements) and a drug card consisting of drugs and there is an adhesive behind the card. Drug cards consist of images of various drugs in Indonesia, especially drugs that are found in everyday life so easily recognized by students. There are about 100 types of drugs presented in this medium. Students are required to think about the main chemical compounds that compose the drug, then students are required to find the compiler element of the compound. One type of drug is made into various cards that have an amount equal to the number of constituent elements so that one drug type can be affixed to the various column elements in the empty periodic table. This drug card also requires learners to think of the position of the constituent elements of the drug in the table so that it will help the students in understanding the group and the element period.

Beginning of learning, a review of the material elemental periodic system and its relationship with the pharmaceutical world. Furthermore, the class is divided into 4 groups with each group consisting of 5 students. The names of the groups the researchers used were the groups of alkali, alkaline, boron, and carbon. After the division of the group, the researcher explains the technicalities of the game to be performed. Implementation of this game is done for 30 minutes and continued with 
confirmation. This confirmation stage is done to match the element in the medication with its position in the periodic table of elements. The implementation of the last innovation is a post-test to measure student's learning motivation and learning outcomes. The post-test consists of 25 questions to measure learning outcomes and 20 points in the motivation questionnaire. Based on the research done got the result of motivation study based on the questionnaire. Questionnaire motivation filled by 20 pharmacy class students. In this innovation got an average result from motivation questionnaire 82,5 and learning outcomes learn 59,2 by counting the score average from all students in questionnaire and post-test.

The criterion of quality of medicine card innovation in terms of motivation can be seen in the following table by Widoyoko (2009):

Table 2. Criteria for Motivation Attainment

\begin{tabular}{cl}
\hline Score & Category \\
\hline $\mathbf{8 4}<x$ & Very good \\
\hline $\mathbf{6 7 , 9 8}<\boldsymbol{x} \leq \mathbf{8 4}$ & Good \\
$\mathbf{5 2 , 0 2}<\boldsymbol{x} \leq \mathbf{6 7 , 9 8}$ & Enough \\
$\mathbf{3 6}<\boldsymbol{x} \leq \mathbf{5 2 , 0 2}$ & Less \\
$\boldsymbol{x}<\mathbf{3 6}$ & Very less
\end{tabular}

From the result of learning, learning outcomes can be seen in the following table.

Table 3. Criteria of learning outcomes.

\begin{tabular}{cl}
\hline Score & Category \\
\hline $\mathbf{8 0 , 0 0 6}<x$ & Very good \\
\hline $\mathbf{6 0 , 0 0 2}<\boldsymbol{x} \leq \mathbf{8 0 , 0 0 6}$ & Good \\
$\mathbf{3 9 , 9 9 8 < x \leq 6 0 , 0 0 2}$ & Enough \\
$\mathbf{1 9 , 9 9 8}<x \leq 39,998$ & Less \\
$x<19,998$ & Very less \\
\hline
\end{tabular}

Table 2 and 3 seem that the average of 82,5 students' motivation is at a good level of $67,98<x$ $\leq 84$, while the average learning outcomes of 59,2 students are at a sufficient level of $39,998<x \leq 60,002$. It is expected that learners of the pharmacy course appear motivation followed by a high awareness that the chemistry in pharmacy. But from the innovation that is done, there are still some shortcomings that need to be fixed that are by looking for more drugs with the arrangement of elements that are more varied so that it can add to the wealth of elements that can be learned in this innovation. 


\section{CONCLUSION}

From the results of the innovations implemented, it can be concluded that:

a. The implementation process of medicine card media innovation in the material of the periodic element system is from the planning, implementation and evaluation stage. In the implementation stage of material explanation, explanation of how to use medicine card, group division, medicine card implementation, and confirmation. While the evaluation stage is done by using a motivation questionnaire with Likert scale and post-test questions.

b. Results from the use of medicine card on student learning motivation are of good quality and if viewed from the students' learning outcomes in enough quality.

\section{ACKNOWLEDGMENTS}

Thank you to Health Vocational School of Sadewa, Sleman, Yogyakarta for supporting this research.

\section{REFERENCES}

[1] Alci, B. (2015). The influence of self efficacy and motivational factors on academic performance in general chemistry course: a modeling study. Academic Journals Educational Research and Reviews, 453-361.

[2] Brophy, J. (2004). Motivating Students to Learning. New Jersey: Lawrence Erlbaum Associates.

[3] Daryanto. (2010). Media Pembelajaran Sangat Penting dalam Mencapai Tujuan Pembelajaran. Yogyakarta: Gava Media

[4] Pintrich, P. R. (2003). A motivational science perspective on the role of student motivation in learning and teaching contexts. Journal of Educational Psycholog, 95, 667-686.

[5] Sardiman. (2011). Interaksi \& Motivasi Belajar Mengajar. Jakarta: PT. Raja Grafindo Persada.

[6] Sa’ud, U. S. (2010). Inovasi Pendidikan. Jakarta: Alfabetha.

[7] Subali, B. (2012). Prinsip Asesmen \& Evaluasi Pembelajaran. Yogyakarta: UNY Press.

[8] Sugihartono. (2012). Psikologi Pendidikan. Yogyakarta: UNY Press.

[9] Widoyoko, E. P. (2009). Evaluasi Program Pembelajaran. Yogyakarta: Pustaka Pelajar, 238. 